\title{
Guilleermo
}

de Delicham

Reseñas $\odot$ Acceso abierto

\section{La sociedad paliativa. El dolor hoy}

\author{
The palliative society. Pain today
}

\author{
Juan David Almeyda Sarmiento \\ ${ }^{i}$ Universidad Industrial de Santander; Bucaramanga; Colombia.
}

Correspondencia: Juan David Almeyda Sarmiento. Correo electrónico: juanalmeyda96@gmail.com

Recibido: 22/06/2021

Revisado: 02/07/2021

Aceptado: 12/07/2021

Citar así: Almeyda Sarmiento; Juan David. (2021). La sociedad paliativa. El dolor hoy. Revista Guillermo de Ockham, 19(2), pp. 363-364.

https://doi.org/10.21500/22563202.5469

Copyright: (C) 2021. Universidad de San Buenaventura, Cali. La Revista Guillermo de Ockham proporciona acceso abierto a todo su contenido bajo los términos de la licencia Creative Commons AttributionNonCommercial-NoDerivatives 4.0 International (CC BY-NC-ND 4.0).

Conflicto de intereses. El autor ha declarado que no hay conflicto de intereses.

Disponibilidad de datos. Todos los datos relevantes están en el artículo. Para mayor información contactar al autor de correspondencia.

Descargo de responsabilidad. El contenido de este artículo es responsabilidad exclusiva del autor y no representa una opinión oficial de su institución ni de la Revista Guillermo de Ockham.
Después de haber delineado el problema de lo ritual dentro del globalizado mundo contemporáneo (cfr. Han, 2020a), este filósofo presenta a principio de año una obra que recopila sus ideas centrales sobre la actualidad del dolor (que a lo largo de la obra se entiende como la máxima expresión de lo negativo), relacionado específicamente con el asunto de la pandemia. Este pequeño tratado encaja perfectamente con el desarrollo teórico que el autor ha formulado con el pasar del tiempo. Esto último se evidencia cuando se mira en retrospectiva su trabajo profundo y detenido sobre las sintomatologías que delimitan lo que el autor denomina la sociedad del rendimiento, a saber: el cansancio, el enjambre, la transparencia y la psicopolítica (Cfrt. Han, 2012; 2013; 2014a; 2014b). Así, lo paliativo surge como una nueva dimensionalidad que forma parte de ese Homo digitalis con el que Han relaciona al ser humano en la era del neoliberalismo digital. Esta nueva característica se identifica con dotar a las personas de una anestesia existencial que imposibilita al ser humano sentir dolor o sufrimiento alguno, por lo que los movimientos dialécticos del espíritu, algo en lo que Han retoma a Hegel (2010), no posibilitan una reconciliación entre lo negativo y lo positivo de la existencia, sino que todo se reduce a la pura positividad. Así, el dolor, junto con su ausencia, es el objeto de estudio sobre el que el libro busca articular un discurso filosófico que supere la limitada visión de la medicina al respecto del mismo contenido. De acuerdo con esta idea, para Han dejarse doler implica una fuerte dirección ética, política, social y existencial: "Los dolores son seńales cifradas. Contienen la clave para entender la respectiva sociedad. Por eso, toda crítica social tiene que desarrollar su propia hermenéutica del dolor" (p. 11). Y es en esta búsqueda de una hermenéutica del dolor que lo paliativo tiene lugar. Esto es, lo paliativo existe como cualidad sui generis del dolor, algo así como un dolor-que-no-es-dolido, en el que se encarna el nuevo horizonte humano de relacionarse con su propia muerte y con la del otro.

Así, para conseguir desarrollar esta hermenéutica particular, el autor se propone once capítulos: 1. Algofobia. 2. Obligación de ser feliz. 3. Supervivencia. 4. Sinsentido del dolor. 5. La astucia del dolor. 6. Dolor como verdad. 7. Poética del dolor. 8. Dialéctica del dolor. 9. Ontología del dolor. 10. Ética del dolor, y 11. El último hombre.

Cada capítulo responde a la necesidad de darle forma a ese proyecto de la hermenéutica del dolor, que no es más que un ejercicio por entender los símbolos y signos escondidos en la relación del ser humano con su propio dolor para, al mismo tiempo, diagnosticar (más que prescribir) la manera como el neoliberalismo digital contemporáneo afecta nuestra propia relación con el sufrimiento, tanto en su forma más inmediata e íntima como en su forma más compleja y relacional. Como el mismo autor lo indica, todo está orientado a constituirse en una crítica social fuerte, la cual no es otra cosa que el proyecto filosófico en el que el coreano lleva años trabajando. La sociedad paliativa es otro ladrillo en el edificio teórico de Han, lo cual indica que es una lectura obligada para quienes son lectores anteriores de este autor, así 
como lectores primerizos, puesto que la obra se toma la molestia de devolverse a explicar cosas de sus libros pasados cuando es requerido.

Claro está que sobre este asunto del dolor, específicamente en lo que refiere a la muerte, el autor ha tenido otras obras en las cuales a podido profundizar con muchísima más calma (Cfr. Han, 2018; 2020b). En estos libros, la muerte se posiciona como la protagonista para dar toda una explicación filosófica sobre lo que implica la relación entre el ser humano con su propia finitud. En comparación, La sociedad paliativa se ve como un esfuerzo por articular sus tratados tanáticos, por llamarlos de alguna forma, con sus tratados societales, lo cual da como resultado un proyecto interesante que les da un papel al dolor y a la muerte desde otro orden, al ponerlos en el marco de una sociedad neoliberal descrita por Han. El Homo digitalis descrito por el autor, junto con la sociedad del rendimiento, son conceptos que en Han siempre están en constante expansión teórica, y una profundización detallada del papel que juega el dolor en todo este andamiaje conceptual se vuelve interesante y oportuno, ya que la obra trae una complementación de lo ya dicho sobre la relación que tendrá el ser humano en lo venidero de su historia tras la pandemia (Han, 2020c).

Más allá de la idea equivocada sobre el hecho de que la filosofía ha callado sobre el dolor, idea afirmada al inicio del libro a modo casi de sentencia lapidaria, esta reciente obra del coreano sí deja ver un ejercicio por poner la filosofía en diálogo con su propio tiempo y además, se esfuerza por dar un entendimiento sobre la situación de la pandemia, algo que se agradece ya que en un a sociedad cada vez más marcada por el silencio de la filosofía, un ejercicio de este tipo es bien recibido tanto por el lector de la academia como por el ciudadano de a pie.

\section{Referencias}

Han, Byung-Chul. (2012). Sociedad del cansancio (A. Saratxaga, trad.). Barcelona: Herder.

Han, Byung-Chul. (2013). Sociedad de la transparencia (R. Gabás, trad.). Barcelona: Herder.

Han, Byung-Chul. (2014a). En el enjambre (R. Gabás, trad.). Barcelona: Herder.

Han, Byung-Chul. (2014b) Psicopolitica. Neoliberalismo y nuevas técnicas de poder (A. Bergés, trad.). Barcelona: Herder.

Han, Byung-Chul. (2018). Muerte y alteridad (A. Ciria, trad.). Barcelona: Herder.

Han, Byung-Chul. (2020a). Desaparición de los rituales. Una topología del presente (A. Ciria, trad.). Barcelona: Herder.

Han, Byung-Chul. (2020b). Caras de la Muerte. Investigaciones filosóficas sobre la muerte (A. Ciria, trad.) Barcelona: Herder.

Han, Byung-Chul. (22 de marzo del 2020c). La emergencia viral y el mundo de mańana. El País, obtenido de: https://n9.cl/02nv

Han, Byung-Chul. (2021). La sociedad paliativa. El dolor hoy. Barcelona: Herder.

Hegel, G. (2010). Fenomenología del espiritu (A. Gómez, trad.) Madrid: Abada Editores. 